\title{
Comparative microbial community composition from secondary carbonate (moonmilk) deposits: implications for the Cansiliella servadeii cave hygropetric food web
}

\author{
Annette Summers Engel ${ }^{1 *}$, Maurizio G. Paoletti ${ }^{2 *}$, Mattia Beggio ${ }^{2}$, Luca Dorigo ${ }^{3}$, \\ Alberto Pamio ${ }^{2}$, Tiziano Gomiero ${ }^{2}$, Claudio Furlan ${ }^{2}$, Mauro Brilli ${ }^{4}$, Angelo Leandro Dreon ${ }^{2}$, \\ Roberto Bertoni ${ }^{5}$, and Andrea Squartini ${ }^{6}$ \\ Department of Earth and Planetary Sciences, University of Tennessee, Knoxville, TN 37996 USA \\ 2 Dipartimento di Biologia, Università di Padova, Agroecology and Ethnobiology, Padova 35100 Italy \\ ${ }^{3}$ Museo di Storia Naturale di Udine, Udine 33100 Italy \\ ${ }^{4}$ Instituto di Geologia Ambientale e Geoingegneria, Dipartimento di Scienze della Terra, Università La Sapienza di Roma, Roma 00185 Italy \\ ${ }^{5}$ CNR Istituto per lo Studio degli Ecosistemi Largo Tonolli 50, Verbania Pallanza 28922 Italy \\ ${ }^{6}$ Dipartimento di Agronomia Animali Alimenti Risorse Naturali e Ambiente, Università di Padova - Agripolis, Viale dell’Università, 16, 10 Legnaro \\ (Padova) 35020 Italy
}

\begin{abstract}
The microbial diversity of moonmilk, a hydrated calcium carbonate speleothem, was evaluated from two Italian caves to provide context for the food web of highly-specialized troglobitic beetles, Cansiliella spp. (Leptodirinae), with distinctive carbon and nitrogen isotope values indicative of a novel food source. The moonmilk and associated percolating waters had low to no extractable chlorophyll, with an average organic $\mathrm{C}: \mathrm{N}$ ratio of 9 , indicating limited allochthonous input and a significant contribution from microbial biomass. The biomass from moonmilk was estimated to be $\sim 10^{4}$ micro- and meiofaunal individuals per $\mathrm{m}^{2}$ and $\sim 10^{7}$ microbial cells $/ \mathrm{ml}$. Proteobacteria dominated the $16 \mathrm{~S}$ rRNA gene sequences retrieved from the moonmilk from both caves. The distribution of other proteobacterial classes and phyla in the moonmilk were statistically similar to each other, even though the two caves are geographically separated from each other. Comparing the moonmilk gene sequences to sequences from previously described environmental clones or cultured strains revealed the uniqueness of the moonmilk habitat, as $\sim 15 \%$ of all of the moonmilk sequences were more closely related to each other than to sequences retrieved from any other habitat. However, comparative analyses confirmed that as much as $\sim 34 \%$ of the clones sequences were also closely related to environmental clones and cultured strains derived from soil and freshwater habitats, which is likely due to the fact that the putative inoculation source for the moonmilk bacterial communities is from overlying soil and percolating fluids from the surface. Prior to our studies of Cansiliella spp., moonmilk has not been considered a food source for cave animals. Our findings provide unique insight into moonmilk microbial diversity that could reveal the underpinnings of the moonmilk carbon and nitrogen cycle that influences the isotopic composition and the morphological adaptations of the troglobitic beetles associated with the moonmilk.
\end{abstract}

Keywords: calcium carbonate; microorganisms; food web; nitrogen cycling; beetles

Received 25 February 2013; Revised 10 June 2013; Accepted 21 June 2013

Citation: $\quad$ Summers Engel A., Paoletti M.G., Beggio M., Dorigo L., Pamio A., Gomiero T., Furlan C., Brilli M., Dreon A.L., Bertoni R. and Squartini A., 2013. Comparative microbial community composition from secondary carbonate (moonmilk) deposits: implications for the Cansiliella servadeii cave hygropetric food web. International Journal of Speleology, 42 (3), 181-192. Tampa, FL (USA) ISSN 0392-6672 http://dx.doi.org/10.5038/1827-806X.42.3.2

\section{INTRODUCTION}

Chemolithoautotrophic microbial processes control metal and nutrient cycling in karst aquifer systems (e.g., Sarbu et al., 1996; Northup et al., 2003; Opsahl \& Chanton, 2006; Gray \& Engel, 2013) and support rich and biologically diverse ecosystems with complex trophic-level interactions and food webs in the absence of allochthonous input (e.g., Holmes et al., 2001; Farnleitner et al., 2005; Goldscheider et al., 2006; Macalady et al., 2008; Birdwell \& Engel, 2009; Birdwell \& Engel, 2010). These findings contradict a long-held tenet that nearly all ecosystems on Earth are dependent on oxidative photosynthesis for energy and organic carbon (e.g., Horner-Devine et al., 2003; Amend \& Teske, 2005; Simon et al., 2007; 
Smith, 2007). However, microbial food webs from subaerially exposed (i.e. terrestrial) mineral deposits in caves have received relatively limited attention with respect to microbial food web structure, depsite their importance for troglobionts (cave-adapted, terrestrial invertebrates) and even the possiblity that their association can alter climate records from speleothem deposits (e.g., Lacelle et al., 2004; Blyth et al., 2008).

Moonmilk -- a spongy to powdery assemblage of microcrystalline carbonate minerals that resembles toothpaste when hydrated -- is a type of secondary carbonate speleothem that occurs subaerially in caves, usually on cave walls (Hill \& Forti, 1997). Microbial and fungal biomass is prevalent in moonmilk (e.g., Cañaveras et al., 2006; Rooney et al., 2010; Baskar et al., 2011; Braissant et al., 2012; Sanchez-Moral et al., 2012). Although some investigations suggest that microbes mediate moonmilk development (e.g., Mason-Williams, 1959; Northup et al., 2000; Cañaveras et al., 2006; Richter et al., 2008), microbes are not essential for its formation (Borsato et al., 2000). Recent studies of moonmilk examine biogeochemical and geomicrobiological interactions (e.g., Mulec et al., 2002; Cacchio et al., 2004; Van de Kamp, 2004; Portillo \& Gonzalez, 2011; SanchezMoral et al., 2012), but there still has been scant effort to evaluate the microbial diversity of moonmilk using culture-independent methods or to consider the possibility that moonmilk, because of the abundance of microbial biomass, may serve as a potential food and energy source for troglobitic invertebrates when allochthonous organic carbon input would be limited (Paoletti et al., 2011). Inclusion of moonmilk into terrestrial cave food web structures represents a significant paradigm shift.

Extensive moonmilk deposits in the Italian caves, Grotta della Foos and Bus della Genziana (Fig. 1A), are associated with the occurrence of Cansiliella, a group of troglobitic beetles. Cansiliella servadeii Paoletti 1972 (Coleoptera: Leptodirinae) browses the interface of percolating waters and moonmilk in Grotta della Foos, and Cansiliella tonielloi is found with moonmilk in Bus della Genziana (Beggio, 2007). Cansiliella spp., as well as other beetles from the genus Hadesia and possibly the recently described genera Radziella, Velebitodromus, Croatodirus, Nauticella, Tartariella, and Kircheria, have body characteristics distinct from the majority of other troglobitic Leptodirinae and have peculiar, semi-aquatic feeding behaviors attributed to inhabiting rocky surfaces, such as cave walls (Jeannel, 1924; Remy, 1940; Paoletti, 1973; 1980; Moldovan et al., 2003; Sket, 2004; Giachino \& Vailati, 2006). Their feeding and mouthpart morphologies suggest a microphagous feeding habit associated with filtration of allochthonous organic material from the hygropetric, cave-wall habitat (Sket, 2004). Prior to our investigations (Paoletti et al., 2009; Paoletti et al., 2011; Paoletti et al., 2013), no previous studies directly evaluated the food source for Cansiliella spp.

Our observations of Cansiliella spp. led to the working hypothesis that microbes associated with the moonmilk serve as food for the beetles. Using stable isotope ratio systematics, we attempted to establish the food web position of $C$. servadeii and other cave animals (including Monolistra lavalensis, Niphargus sp., and Androniscus noduliger) with respect to moonmilk (Paoletti et al., 2011). The carbon isotope values of $C$. servadeii are consistent with moonmilk potentially serving as a food source. However, potential overgrazing of the moonmilk by the beetle to obtain sufficient nutrition, and unique and even unknown microbial activities in the moonmilk associated with nitrogen cycling, suggest that the trophic level position for $C$. servadeii is incompatible with moonmilk serving as a food source. Therefore, the goal of the current study is to enhance our understanding of moonmilk microbial diversity from Grotta della Foos and Bus della Genziana that could reveal the underpinnings of a moonmilk nitrogen cycle. This research identifies a common community structure for the moonmilk bacterial communities, and also offers an explanation for why some troglobitic invertebrates, such as $C$. servadeii, have evolved unique body morphologies and behaviors to take advantage of a cave hygropetric habitat like moonmilk.
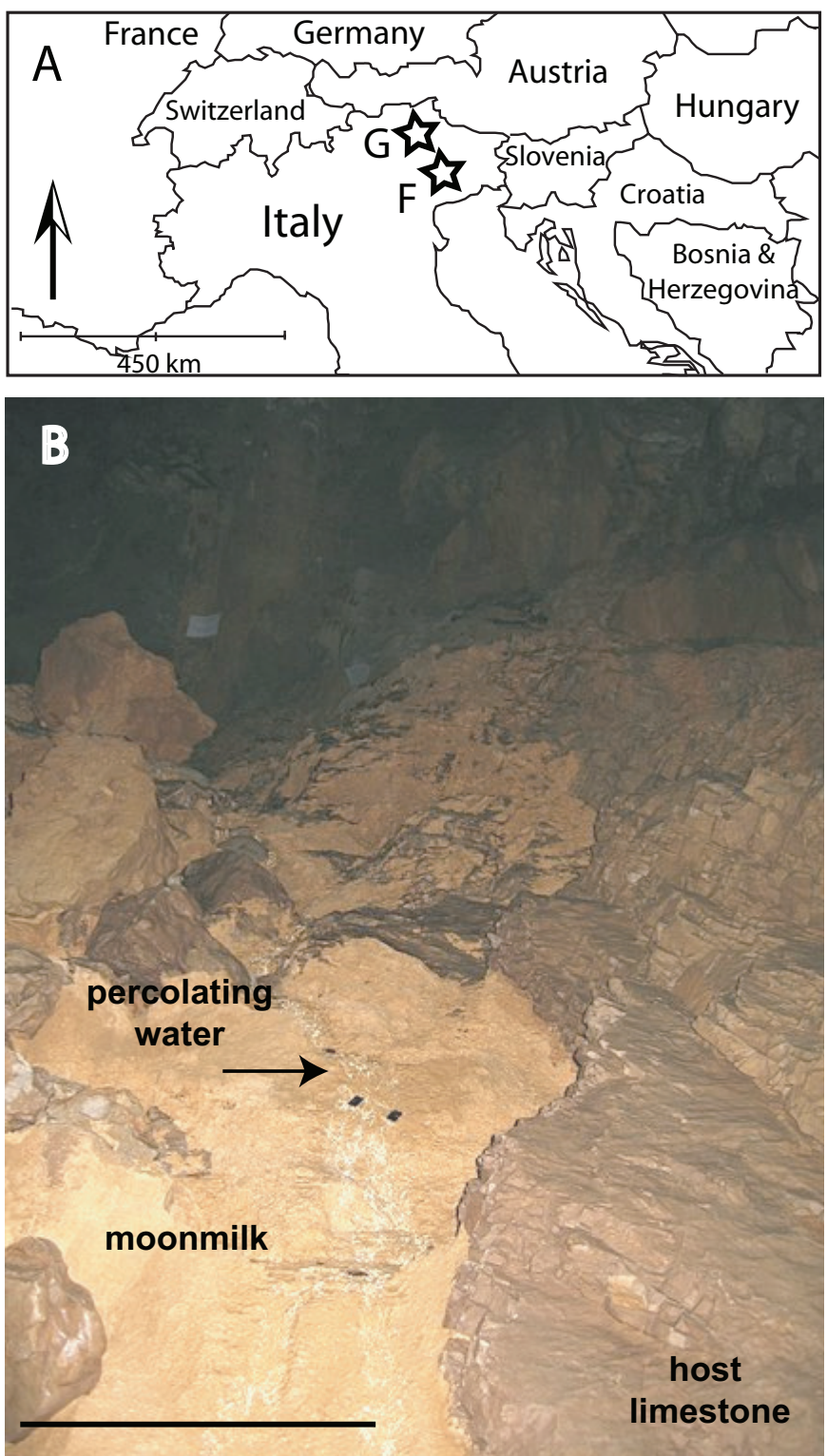

Fig. 1. (A) General location map for Grotta della Foos, Italy (star labeled "F") and Bus della Genziana (star labeled "G") with (B) one of the moonmilk sampling sites in Grotta della Foos, modified from Paoletti et al. (2011). Scale bar $=0.5 \mathrm{~m}$. 


\section{MATERIALS AND METHODS}

\section{Sample collection}

Moonmilk was collected from Grotta della Foos in March 2008 and from Bus della Genziana in January 2009 (Beggio, 2007). Both caves formed in Cretaceous limestone, and Grotta della Foos is located at an elevation of $422 \mathrm{~m}$ and Bus della Genziana at $1020 \mathrm{~m}$. The primary sample location in Grotta della Foos where $C$. servadeii is found is "Site B" (Fig. 1) (Paoletti et al., 2011). Further sampling location details are withheld because the Cansiliella spp. population sizes are not known and the caves are not well-protected, although Bus della Genziana is located in a natural speleological preserve (Paoletti et al., 2011).

\section{Aqueous geochemistry and moonmilk characterization}

Basic geochemical analyses of percolating water samples were done, including $\mathrm{pH}$, temperature, and specific conductance. Water was filtered to $0.2 \mu \mathrm{m}$, and anions and cations were measured by single column ion chromatography. The geochemical program PhreeqcI version 2.15.0 was used to determine the saturation indices (SI) of mineral phases according to the logarithm of the quotient of the ion activity product and solubility product constant (Parkhurst \& Appelo, 1999). Organic carbon compositions were measured following the removal of inorganic carbonate with a solution of $1 \mathrm{~N}$ $\mathrm{HCl}$ for $16 \mathrm{hr}$ at room temperature while monitoring the reaction and $\mathrm{pH}$ (Midwood \& Boutton, 1997). Samples for each were rinsed to about $\mathrm{pH} 5.5$ in DI $\mathrm{H}_{2} \mathrm{O}$, dried at $50{ }^{\circ} \mathrm{C}$, and then ground to a fine powder. Because the acidification procedure could produce a loss of nitrogen-acid soluble organic matter and enhance ingassing of $\mathrm{NH}_{3}$, nitrogen content was done on non-acidified samples. Aliquots were flash combusted on an EA 1110 Carlo Erba elemental analyzer.

Moonmilk from Bus della Genziana was thinner and patchier, making collection for additional geochemical and biological characterization difficult. Therefore, examination of chlorophyll content and meiofaunal and microbial cell counts (below) was done only from Grotta della Foos. Chlorophyll and photosynthetic pigment content ( $\mathrm{Chl}$ a) was measured spectrophotometrically to assess the potential presence of photosynthetically-derived (allochthonous) organic matter. For the water, the method of Innamorati (1990) was used. Briefly, 0.5 to $1 \mathrm{~L}$ of water was filtered onto a $1 \mu \mathrm{m}$ glass fiber filter, which was placed into $80 \%$ acetone. The filter-acetone mixture was ground, then incubated for $24 \mathrm{hr}$ before centrifugation. For moonmilk, the following modifications were made from Innamorati (1990). Moonmilk was dried for $24 \mathrm{hr}$ at $60^{\circ} \mathrm{C}$. The dried material was pulverized and $1 \mathrm{~g}$ was used to extract chlorophyll using 1:1 chloroform-methanol. The slurry was incubated for $24 \mathrm{hr}$, than centrifuged for $25 \mathrm{~min}$ at $4000 \mathrm{rpm}$. Absorbance was measured from the supernatant. Detailed calculations can be found in Beggio (2007).

\section{Micro- and meiofaunal and microbial cell counts}

Twenty glass slides were placed in the percolating water on the surface of moonmilk at Site B in Grotta della Foos (Fig. 1) for $\sim 5$ months to capture and enumerate micro- and meiofauna. Slides were transported to the lab in sterilized boxes containing the same percolating water and maintained at $4{ }^{\circ} \mathrm{C}$ until analysis. Slides were examined by stereomicroscope and transmission microscope for general identification. For microbial cell abundance, aliquots of the moonmilk with associated percolating waters were fixed in $4 \%$ formaldehyde. Briefly, 1 $\mathrm{ml}$ of the moonmilk slurry was resuspended in 5 $\mathrm{ml}$ of MQ water and vortexed for $5 \mathrm{~min}$. An aliquot of $1 \mathrm{ml}$ of suspension or $1 \mathrm{ml}$ of water was vacuum filtered on a $0.2 \mu \mathrm{m}$ pore size polycarbonate filter (Nuclepore) and stained with DAPI ( $\alpha$, 6-diamino-2phenylindole) at a final concentration of $0.2 \% \mathrm{wt} / \mathrm{vol}$ (Porter \& Feig, 1980). Cell counts were done with a Zeiss Axioplan epifluorescence microscope, equipped with an HBO $100 \mathrm{~W}$ lamp, a Neofluor 100 x objective, $1.25 \mathrm{x}$ additional magnification, and filter sets for UV light excitation (Zeiss filter set G365, FT395, LP420). Microscopic fields for counting were grabbed with an image analysis system (Image ProPlus; Media Cybernetics, Silver Spring, MD, USA), equipped with a high sensitivity video camera (CoolSNAP Pro-cf, Media Cybernetics).

\section{DNA extraction from moonmilk and percolating waters}

Two separate samples of moonmilk from Grotta della Foos were collected from Site B (referred to as "Foos7B" and "Foos8B"), and one site from Bus della Genziana (referred to a "GMM"). Total environmental nucleic acids were extracted within $72 \mathrm{hr}$ of collection. Various extraction methods were considered (e.g., Barton et al., 2006), but based on cell count estimates from DAPI, the following method was considered sufficient to retrieve high purity, representative DNA from the microbial community in the moonmilk. Specifically, 2 $\mathrm{ml}$ of moonmilk slurry were placed into $10 \mathrm{ml}$ of sterile cell lysis buffer $(10 \mathrm{mM}$ Tris and $100 \mathrm{mM}$ EDTA, pH 8.0), homogenized with a sterile tissue homogenizer for $2 \mathrm{~min}$, or until large particles and clumps were thoroughly disaggregated to particles no bigger than grains of sand. The suspensions were incubated at $55^{\circ} \mathrm{C}$ on a shaker overnight at $250 \mathrm{ppm}$, following addition of $40 \mathrm{ml}$ of proteinase $\mathrm{K}(20 \mathrm{mg} / \mathrm{ml})$. Protein precipitation was accomplished by combining $1 \mathrm{ml}$ of cooled suspension with $1 \mathrm{ml} 7.5 \mathrm{M}$ ammonium acetate. The solutions were mixed thoroughly, and then incubated on ice for $15 \mathrm{~min}$ prior to centrifugation for $5 \mathrm{~min}$ at high speed. The supernatant was transferred to a new tube with an equal volume of $100 \%$ isopropanol for nucleic acids precipitation overnight at $4^{\circ} \mathrm{C}$. Samples were centrifuged at high speed for $3 \mathrm{~min}$ and pellets were washed with cold, 95\% ethanol. Nucleic acids were rehydrated in $50 \mathrm{ml}$ TE buffer $(10 \mathrm{mM}$ Tris and 0.1 mM EDTA, pH 8.0). DNA purity and concentrations for each extraction were determined on a NanoDrop ND-1000 spectrophotometer (NanoDrop Technologies, LLC, USA). 


\section{PCR amplification of genomic DNA, cloning, and sequencing}

Nearly full length 16S rRNA gene sequences were obtained by PCRamplification using the bacterialprimer pair 8f (forward, 5'-AGAGTTTGATCCTGGCTCAG-3') and 1510r (reverse, 5'-GGTTACCTTGTTACGACTT-3') (Lane, 1991). The archaeal primers UA571F (forward, 5'-GCYTAAAGSRICCGTAGC-3') and UA1204R (Reverse, 5'-TTMGGGGCATRCIKACCT-3') (Baker \& Cowan, 2004) were also used, but amplifications were unsuccessful. Amplification was performed with a MJ Research Dyad Disciple thermal cycler with 5 U/ $\mathrm{ml}$ ABGene Taq DNA polymerase (ABGene, Thermo Fisher Scientific, USA). Optimal PCR products for bacteria were achieved for three of the four extractions using the following conditions: an initial hot start at $94^{\circ} \mathrm{C}$ for $4 \mathrm{~min}$, followed by denaturation at $94^{\circ} \mathrm{C}$ for $1 \mathrm{~min}$, primer annealing at $47^{\circ} \mathrm{C}$ for $1 \mathrm{~min}$, chain extension at $72^{\circ} \mathrm{C}$ for $1 \mathrm{~min}$, repeated for 29 more cycles, followed by a final extension step for $20 \mathrm{~min}$ at $72^{\circ} \mathrm{C}$.

Amplified PCR products were purified by using a $0.7 \%$ TAE low-melt agarose gel with a Wizard PCR prep DNA Purification kit (Promega Corp., USA), following manufacturer recommendations. Concentrations and purity were determined by spectrophotometry. Purified products were cloned using the TOPO Cloning Kit with the pCR2.1-TOPO ${ }^{\circledR}$ vector, according to manufacturer instructions (Invitrogen Corp., USA); ligation reactions were run overnight at $14^{\circ} \mathrm{C}$. Clones were screened by PCR with the M13-Forward (5'-GTAAAACGACGGCCAG-3') and M13-Reverese (5'-CAGGAAACAGCTATGAC-3') primers (Invitrogen Corp., USA). Amplified inserts were diluted and sequenced by capillary Sanger sequencing using High-throughput Sequencing Solutions (http://www. htseq.org/index.html). Sanger sequencing was chosen over other, more high-throughput methods (e.g., 454 tag pyrosequencing) in order to obtain near-full length 16S rRNA gene sequences for detailed phylogenetic analyses.

\section{Phylogenetic analysis and estimation of microbial diversity}

Resulting 16S rRNA gene sequences were assembled using ContigExpress, a component of Vector NTI Advance 10.3.0 (Invitrogen Corp., USA), and subjected to BLAST searches using GenBank (http://www.ncbi.nlm.nih.gov/) to establish gene sequence similarities to culturable and not yet cultured organisms. Sequences were screened for chimera and aligned using greengenes NAST-aligner (http://greengenes.lbl.gov) and using the program DECIPHER's Find Chimera tool (http://decipher.cee. wisc.edu/FindChimeras.html) (Wright et al., 2011). The Ribosomal Database Project (RDP), release 10 (Cole et al., 2009), Library Compare online analysis tool (Wang et al., 2007) was used to test for statistical differences in the taxonomic representation between the two moonmilk bacterial clone libraries, at alpha = 0.01 and a 95\% confidence threshold.

Designation of operational taxonomic units (OTUs) representing the $\geq 97 \%$ sequence similarity predicted for species-level relationships using 16S rRNA gene sequences (e.g., Stackebrandt \& Goebel, 1994) was done in DOTUR using the furthest-neighbor clustering algorithm (http://www.plantpath.wisc. edu/fac/joh/dotur.html) (Schloss \& Handelsman, 2005). If the DOTUR $\geq 97 \%$ sequence similarity groups were concordant with a monophyletic clade from the reconstructed phylogeny, then those groups were designated as OTUs. Rarefaction curves were generated using DOTUR. More than 400 clone sequences from this study and sequences identified from RDP and BLAST, including outgroup taxa, were used to reconstruct a phylogeny based on a GTR $+\mathrm{G}$ model of evolution. Branch support from 500 bootstrap replicates was constructed using the program MEGA (ver. 5.0) (Kumar et al., 2004) based on the JukesCantor model (Tamura et al., 2004). The phylogenetic associations for the moonmilk clones were evaluated from RDP SeqMatch analysis tool, whereby the highest similarity scores (as S_ab) to environmental clones or cultured strains were compiled and specific habitat types were evaluated (e.g., cave, freshwater, soil, other). Scores of 1.0 would result for identical sequences; the closer the score is to 1.0 , the more similar sequences are to each other. Scores $>0.96-98$ loosely correlate to genus-level associations.

\section{Nucleotide sequence accession numbers}

Representative 16S rRNA gene sequences from Grotta della Foos moonmilk clone libraries were submitted to GenBank under the accession numbers EU431666-EU431834 and KC255251-KC255375 for Bus della Genziana samples.

\section{RESULTS AND DISCUSSION}

\section{Moonmilk geochemistry}

The percolating waters flowing over Grotta della Foos moonmilk (Fig. 1B) had a pH of 8.3 at $8.8^{\circ} \mathrm{C}, 200 \mu \mathrm{S} /$ $\mathrm{cm}$ specific conductance, and $0.3 \mathrm{mmol} / \mathrm{L}$ dissolved oxygen (Table 1). The water associated with the Bus della Genziana moonmilk had a $\mathrm{pH}$ of 7.98 at $7.0^{\circ} \mathrm{C}$, $390 \mathrm{mS} / \mathrm{cm}$ specific conductance, and $0.24 \mathrm{mmol} / \mathrm{L}$ dissolved oxygen (Table 1). For both caves, the water types were characterized as $\mathrm{Ca}-\mathrm{HCO}_{3}{ }^{-}$type (Table $1)$. The waters were supersaturated with respect to calcite (Saturation Index $=+0.43$ ) and undersaturated with respect to other mineral phases, confirming the mineralogy of each deposit, although the Bus della Genziana moonmilk appeared to be less hydrated and in a state of erosion rather than deposition.

The moonmilk from Grotta della Foos was soft, whitish to yellowish color, hydrated and of calcite mineralogy. The density of $C$. servadeii on the moonmilk was $\sim 8-12$ individuals per $\mathrm{m}^{2}$ (Fig. 1B). The organic $\mathrm{C}$ composition of the moonmilk was 0.06-0.52\%, with 0.01-0.05\% organic N, and no detectable $\mathrm{S}$ but minor amounts of $\mathrm{Al}, \mathrm{Si}$, and $\mathrm{Fe}$ (data not shown). By contrast, the Bus della Genziana moonmilk was markedly thinner and patchier, but also of calcite mineralogy. Traces of chlorophyll and other photosynthetic pigments, as proxies for surfacederived (plant) material, were measured from Grotta 
Table 1. Geochemistry of percolating waters. Ions are listed in $\mathrm{mmol} / \mathrm{L}$ concentrations.

\begin{tabular}{|c|c|c|}
\hline & Grotta della Foos & Bus della Genziana \\
\hline Air temperature $\left({ }^{\circ} \mathrm{C}\right)$ & 8.6 & 6.2 \\
\hline Water temperature $\left({ }^{\circ} \mathrm{C}\right)$ & 8.8 & 7 \\
\hline $\mathrm{pH}$ & 8.25 & 7.89 \\
\hline Conductivity $(\mu \mathrm{S} / \mathrm{cm})$ & 225 & 390 \\
\hline Dissolved oxygen (mmol/L) & 0.34 & 0.24 \\
\hline $\mathrm{Na}^{+}$ & 0.01 & 1.10 \\
\hline $\mathrm{K}^{+}$ & $<0.001$ & 0.1 \\
\hline $\mathrm{NH}_{4}^{+}$ & 0.02 & $<0.003$ \\
\hline $\mathrm{Ca}^{2+}$ & 1.13 & 1.15 \\
\hline $\mathrm{Mg}^{2+}$ & $<0.002$ & 0.04 \\
\hline $\mathrm{Cl}^{-}$ & 0.03 & 1.65 \\
\hline $\mathrm{HCO}_{3}^{-}$ & 2.45 & 2.16 \\
\hline $\mathrm{NO}_{2}^{-}$ & 0.04 & $<0.0008$ \\
\hline $\mathrm{NO}_{3} \cdot$ & 0.07 & 0.06 \\
\hline $\mathrm{PO}_{4}^{3 \cdot}$ & 0.002 & $<0.0005$ \\
\hline $\mathrm{SO}_{4}{ }^{2-}$ & 0.04 & 0.03 \\
\hline
\end{tabular}

della Foos percolating waters extractions during the summer $(0.38 \pm 0.14 \mathrm{mg} / \mathrm{l} \mathrm{Chl} \mathrm{a)}$, but nothing was detected from samples collected in the winter. Only moonmilk collected from the summer had detectable quantities of chlorophyll, with a composition of $0.14 \pm 0.09 \mu \mathrm{g} / 1 \mathrm{Chl}$ a. Therefore, it is not possible to rule out that surface-derived organics, even at ultraoligotrophic concentrations, are brought to the area where moonmilk forms in Grotta della Foos. However, the relative contribution of allochthonous material to the overall organic matter composition in the moonmilk does appear to vary seasonally.

\section{Microbial biomass from Grotta della Foos moonmilk}

Because of comparatively easier access compared to the other caves, the percolating waters from Grotta della Foos were examined on several occasions for micro- and meiofauna, such as protists or annelids (Beggio, 2007). Repeated examination of the percolating waters, and even the moonmilk, resulted in infrequent and low numbers of individuals (mean $\sim 10^{4}$ individuals $/ \mathrm{m}^{2}$ ) (O. Coppellotti, unpublished results). Of the identified groups, none are known to be specialized to the subsurface: Glaucoma scintillans (a benthic ciliate), flagellates belonging to the genera Anisonema, Bodo, and Cercomonas, Chironomidae larvae (possibly Eukiefferiella), and an annelid from the Lumbriculidae. Microbial cells were cocciod, bacilliform, or filamentous, and most were a few microns or less in diameter. Rare fungal hyphae were observed, suggesting that fungi do not comprise a significant portion of the moonmilk microbial communities. Cell counts from water were conservatively estimated to be $10^{5}-10^{6}$ cells $/ \mathrm{ml}$, which is similar to what has been reported previously as $10^{3}-10^{6}$ cells $/ \mathrm{ml}$ for epikarst waters (e.g., Rusterholtz \& Mallory, 1994; Laiz et al., 1999). We considered the counts to be a mixture of viable and nonviable cells from the system. We were unable to quantify the number of cells precisely from the moonmilk because high carbonate mineral content (Fig. 2A) interfered with the DAPI signal (Fig. 2B). Nonquantitative estimates revealed that cell numbers in the moonmilk could be 10 to 100 times greater compared to the percolating waters. These microbial biomass estimates would be comparable to those reported by other investigators. Braissant et al. (2012) estimate approximately $10^{5}$ colony forming units (CFUs) per gram of moonmilk from Swiss caves using culture-based and microcalorimetric analyses, and Curry et al. (2009) also describe $10^{4}-10^{6}$ cells as CFUs per gram of moonmilk from Alaska, depending on the type of moonmilk. Considering the abundance of moonmilk in both caves, there is noteworthy microbial standing stock to cycle organic carbon (e.g., del Giorgio \& Cole, 1998; Eiler et al., 2003).

\section{Phylogenetic analysis of microbial communities from moonmilk}

16S rRNA gene sequences were retrieved from moonmilk to evaluate the microbial diversity, which was expected to be high based on previous research of natural, cave-wall habitats (e.g., Northup et al., 2003; Chelius \& Moore, 2004; Van de Kamp, 2004; Barton et al., 2007) and cave-walls with Paleolithic paintings or system having been anthropogenically impacted (e.g., Groth \& Saiz-Jimenez, 1999; Schabereiter-
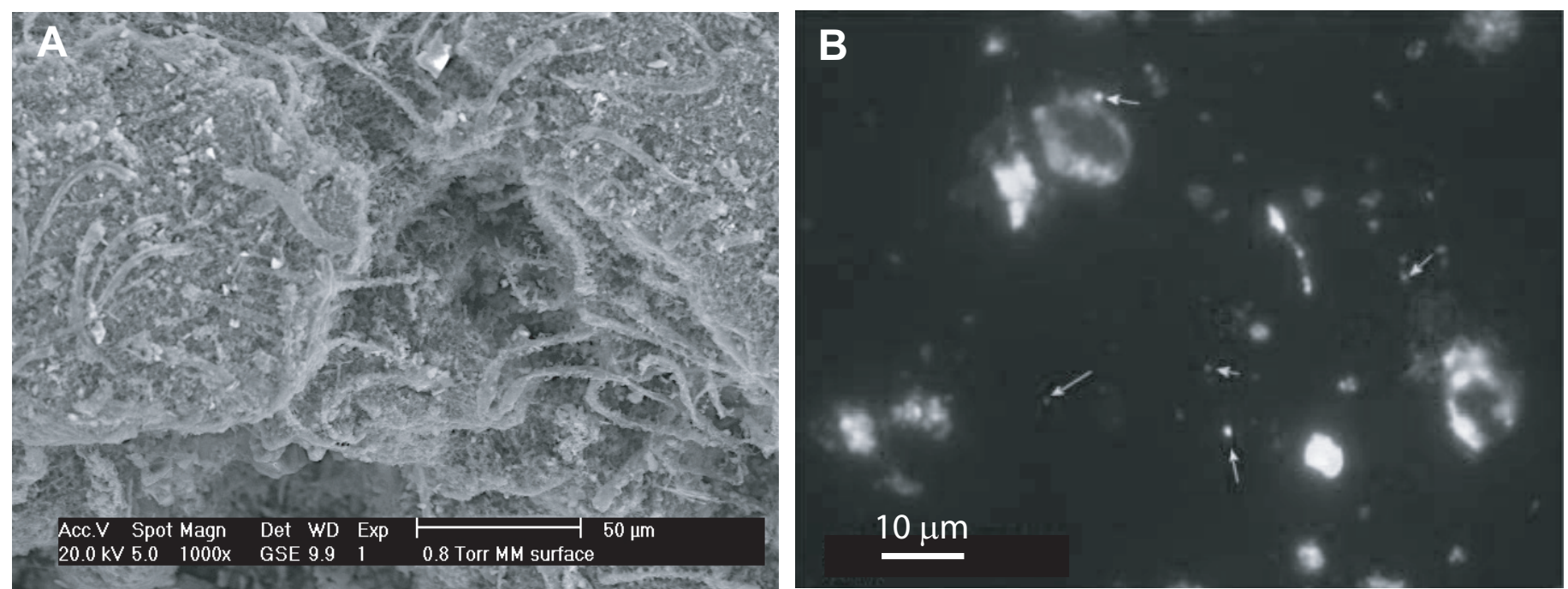

Fig. 2. (A) Environmental scanning electron photomicrograph of moonmilk from Grotta della Foos showing cocciod, bacilliform, and filamentous cells intermixed with microcrystalline calcite. Scale bar $=50 \mu \mathrm{m}$ (B) DAPI-stained cells (arrows) from a slurry of moonmilk. Other, larger bright spots are calcite crystals. Scale bar is $10 \mu \mathrm{m}$. 


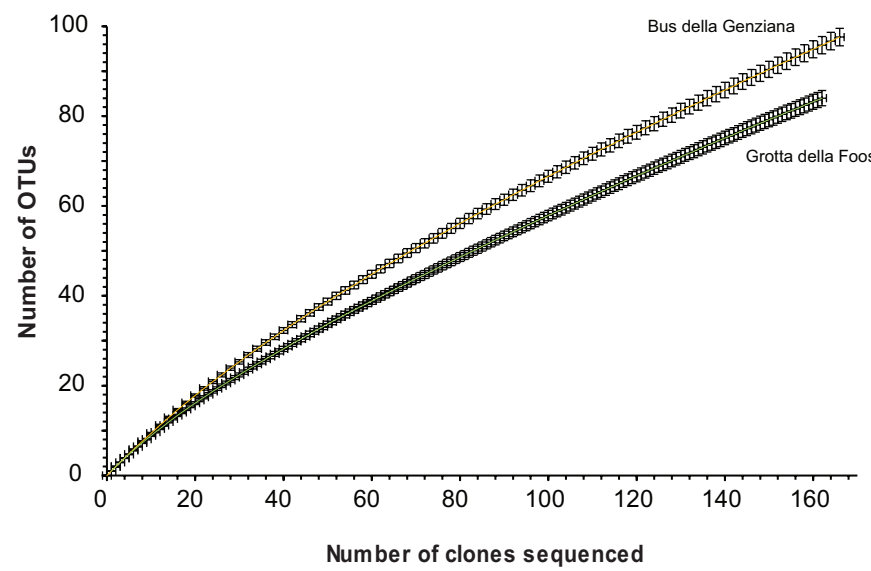

Fig. 3. Rarefaction curves generated at $97 \%$ sequence similarities for bacterial 16S rRNA gene sequence clones from Grotta della Foos and Bus della Genziana moonmilk.

Gurtner et al., 2002b; Schabereiter-Gurtner et al., 2002a; Schabereiter-Gurtner et al., 2004; Ikner et al., 2007). At $97 \%$ sequence similarity, corresponding loosely to interpreted species-level relationships, 187 novel OTUs were identified from the two moonmilk deposits. Although both samples appeared to be under-sampled based on rarefaction analyses (Fig. 3) and that more diversity could be uncovered with additional sequencing efforts, all of the clones were affiliated with, at most, 12 major taxonomic groups, including 2 candidate divisions (Fig. 4). A comparable level of bacterial diversity has also been noted from moonmilk in Ballynamintra Cave, Ireland (Rooney et al., 2010), and Altamira Cave, Spain (Portillo \& Gonzalez, 2011), although near-full length 16S rRNA gene sequences were not produced in these studies so comparison of the communities from the Italian systems and other moonmilk deposits is difficult.

From moonmilk deposits in our study, the majority of clones ( $>50 \%$ of each clone library) were affiliated with the Proteobacteria phylum (Fig. 4A). For Grotta della Foos, more clones were affiliated with the Betaproteobacteria (22.2\%) compared to Alphaproteobacteria (16.3\%) or Gammaproteobacteria (15.9\%). But, for Bus della Genziana, more clones were affiliated with the Alphaproteobacteria (20.4\%), compared to the Betaproteobacteria (15\%) or Gammaproteobacteria (17.3\%). However, the taxonomic representation for the two sites was not statistically different from each other at the phylum, class, or order levels except in one case (Fig. 4B). At the genus-level, 29 of 50 different genera were identified from both sites, representing $>45 \%$ of each of the clone library sequences. Collectively, these results imply that there may be some commonality among the moonmilk microbial communities even though the caves are geographically separated from each other.

A statistically significant difference between the two sites was only noted for the Oxalobacteraceae family $(p=0.003)$ within the Betaproteobacteria, which represented $22.2 \%$ and $15 \%$ of the clones for Grotta della Foos and Bus della Genziana, respectively. Representatives from the Burkholderiales order (Betaproteobacteria), and specifically either the Comamonadaceae or the Oxalobacteraceae families, dominated both moonmilk samples (Fig. 4B; Suppl. Fig. 1). The moonmilk clones were related to other environmental clones and cultured representatives characterized as being chemoorganotrophic, nonfermentative, aerobes common to freshwater and soils and that grow optimally at circumneutral pH (e.g., Grimes et al., 1997; Li et al., 2004; Gillis $\&$ De Ley, 2006) (Suppl. Fig. 1). Clones from Grotta della Foos formed a novel clade within the Acidovorax genus (Comamonadaceae), which are known to grow chemolithoautotrophically using hydrogen as an energy source, while others are capable of denitrification (Heylen et al., 2008). An isolate belonging to the Acidovorax was also retrieved from Ballynamintra Cave moonmilk using minimal medium agar (Rooney et al., 2010), suggesting that there may be some common microbial groups in moonmilk from different caves. From the Italian moonmilk, at least three other novel clades were affiliated with the genera Janthinobacterium and Massilia spp. (Oxalobacteraceae), at 92-97\% sequence similarities. These groups are strict aerobic chemoorganotrophs and are associated with nitrogen cycling, found in aquatic, soil, and metal-contaminated sites, and form plant associations, usually as pathogens (Suppl. Fig. 1). They have also been identified from naturally oligotrophic, but not associated with cave paintings, cave-wall surfaces (e.g., Northup et al., 2003; Barton et al., 2007). The general phylogenetic similarities, even in the absence of high sequence identities, may indicate that the cave habitat, irrespective of geochemical or mineralogic conditions, may be a common habitat for these betaproteobacterial groups.

Other prevalent proteobacterial groups from the moonmilk included the Gammaproteobacteria (Suppl. Fig. 2), Alphaproteobacteria Deltaproteobacteria (Suppl. Fig. 3), and members of the candidate division TM7. Among the Gammaproteobacteria (Fig. 4B; Suppl. Fig. 2), clones were predominately related to various pseudomonad species (Pseudomonadales order). Clones related to Acinetobacter spp. were retrieved from Grotta della Foos. Isolates belonging to this genus cause carbonate precipitation in cultures collected from carbonate speleothems from Cervo Cave, Italy (Cacchio et al., 2004). Other notable genera included Lysobacter spp., a predatory group (Jurkevitch \& Davidov, 2006), and Perlucidibaca and Rhizobacter spp. Among the Alphaproteobacteria (Fig. 4B; Suppl. Fig. 3), retrieved clones were closely related $(93-99 \%$ sequence identity) to groups that also cycle nitrogen, including the genera Sphingomonas, Sphingopyxis, and Novosphingobium (Sphingomonadales order) and Azospirillum (Rhodospirillales order) (Suppl. Fig. 3). These organisms are obligate aerobes and have the ability to fix $\mathrm{N}_{2}$ (Addison et al., 2007). Several clades within the Sphingomonadales were comprised of clones from both moonmilk sites, and were more closely related to each other than to previously retrieved environmental clones or cultured strains. Schabereiter-Gurtner et al. (2004) retrieved similar alphaproteobacterial groups from cave-wall rock and Paleolithic paintings in Spain, and Northup et al. (2003) found these genera from caves in New Mexico. 
These results suggest that the moonmilk and similar cave and karst habitats likely contain additional novel diversity. Deltaproteobacteria associated with the genera Bdellovibrio, Pedobacter, and Haliangium were retrieved from both caves (Suppl. Fig. 3), but had only previously been reported from the Movile Cave in Romania. Bdellovibrio spp. are also obligate predatory bacteria (Jurkevitch \& Davidov, 2006).

The Bacteroidetes phylum represented the second most abundant group at the phylum-level (Fig. 4A), and comprised $16.7 \%$ and $14.9 \%$ of all clone sequences from Grotta della Foos and Bus della Genziana, respectively. Clones were affiliated with predominately the Sphingobacteria class, but representation among the Flavobacteria was also relatively high (Suppl. Fig. 4). Some of the retrieved clones affiliated with the Flexibacter spp. were related to strains previously identified as aerobic chemoorganotrophs from freshwater settings, including a novel clade of Bus della Genziana clones with a sequence from the Frasassi Caves, Italy, and another clade of Grotta della Foos clones and a karst soil clone. Several clones from both caves formed clades within the Flavobacterium genus and were related to known chemoorganotrophs, facultative aerobes, as well as $\mathrm{N}_{2}$ fixers.

Three OTUs (at 97\% sequence identity) belonged to the candidate division TM7, with one large novel clade of Grotta della Foos sequences and other clades with

A

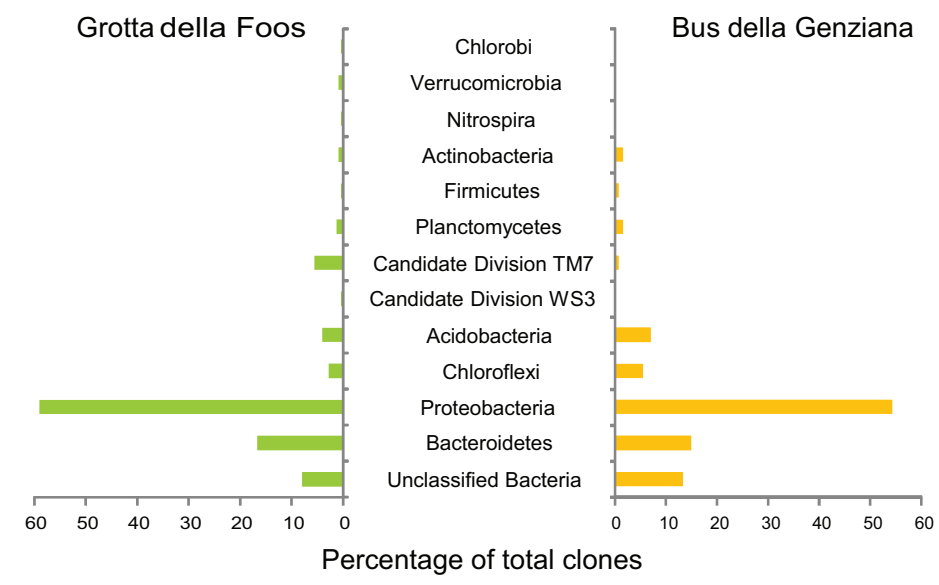

B

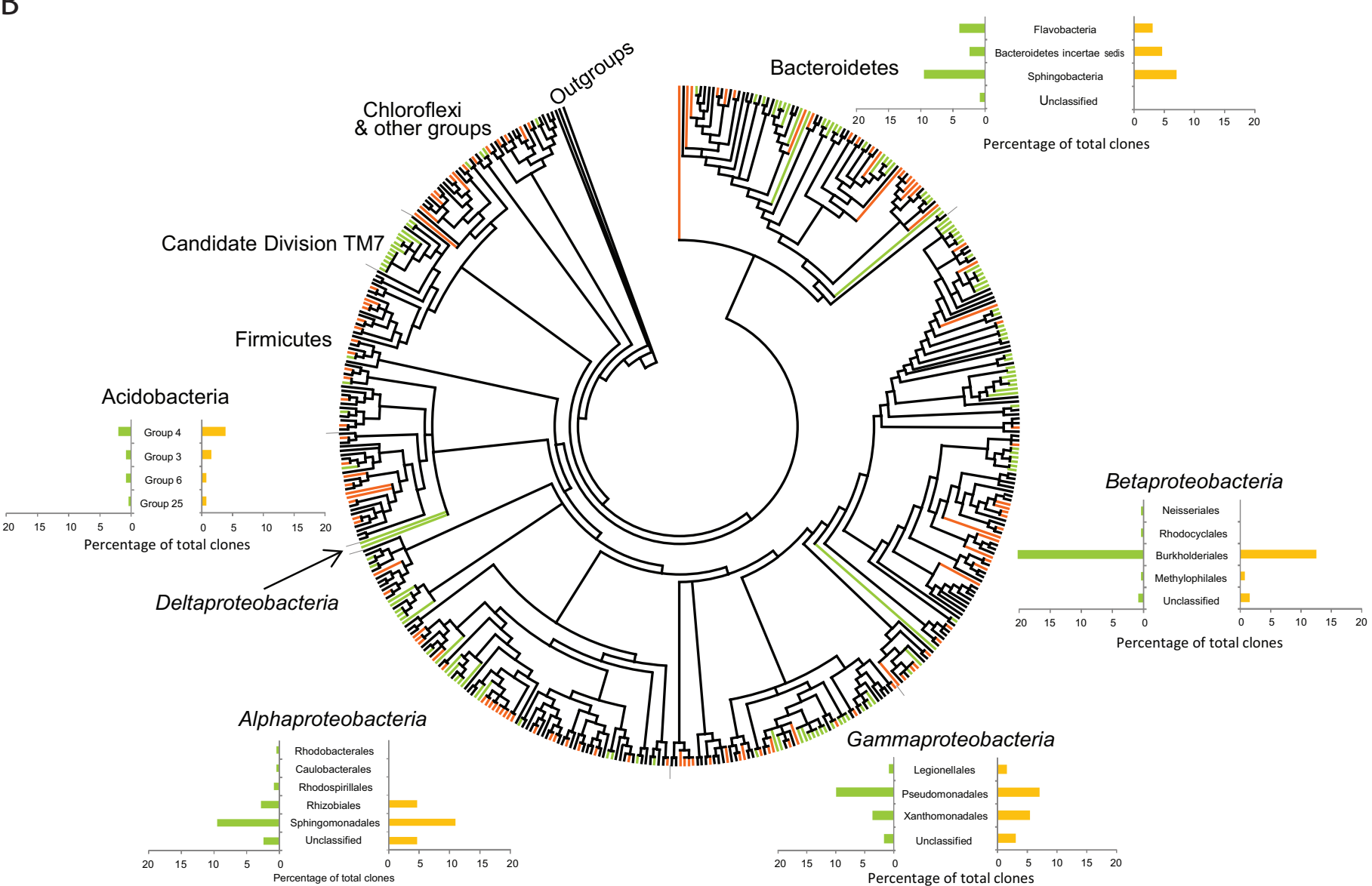

Fig. 4. (A) Summary of the percentage of total 16S rRNA gene sequence clones from Grotta della Foos (colored in green) and Bus della Genziana (colored in orange). (B) Phylogenic reconstruction using neighbor joining topology for 16S rRNA gene sequences of representative bacterial clones retrieved from Grotta della Foos and Bus della Genziana moonmilk samples. Branches linked to sequences retrieved from this study are colored in either green or orange, corresponding to each of the caves. The bar graphs located around the tree show the total percentage of clones affiliated with the specific taxonomic groups to the class level for Bacteroidetes and to the order level for the proteobacterial groups. 
Bus della Genziana clones and other environmental sequences (Fig. 4B). The ecophysiology of the TM7 candidate division remains a mystery (Podar et al., 2007), but finding that these microbes occur in the moonmilk may add to the known metabolic capabilities and physiological requirements for members of this group. To our knowledge, sequences affiliated with the TM7 candidate division have not been retrieved from caves, suggesting that the presence in moonmilk from both caves requires further investigation.

Several culture-independent studies from cave and karst habitats have retrieved sequences belonging to the Verrucomicrobia, Planctomycetes, and Acidobacteria (e.g., Chelius \& Moore, 2004; Ikner et al., 2007). Collectively, these groups were represented by $<2 \%$ each of all of the clones from both Grotta della Foos and Bus della Genziana (Fig. 4A). Verrucomicrobia were only retrieved from Grotta della Foos. Among the Planctomycetes from both sites, none of the clones had high sequences similarities to cultured representatives, but one clone was related to an environmental clone from an 'anammox' reactor, suggesting that anaerobic oxidation of ammonium may be occurring in the moonmilk community. If anammox is occurring, although based on the measured dissolved oxygen concentrations of 0.3 $\mathrm{mmol} / \mathrm{L}$, this is unlikely (e.g., Strous et al., 1998), then this metabolism could impact nitrogen isotope systematics of the moonmilk because anammox is associated with large isotopic fractionation (Paoletti et al., 2011). Retrieving four different groups of Acidobacteria in both moonmilk sites is interesting because this group has also been found to have high abundance on cave-walls (Chelius \& Moore, 2004; Ikner et al., 2007), as well as cave surfaces associated with paintings (Schabereiter-Gurtner et al., 2002a).

Other moonmilk clones were associated with the Actinobacteria, Firmicutes, Nitrospirae, Chloroflexi, Chlorobi, and candidate division WS3. Actinobacteria and Firmicutes have been identified from numerous cave settings (e.g., Groth \& Saiz-Jimenez, 1999; Laiz, 1999; Schabereiter-Gurtner et al., 2002a; Northup et al., 2003; Chelius \& Moore, 2004; Gerič et al., 2004; Schabereiter-Gurtner et al., 2004; Van de Kamp, 2004; Barton et al., 2007; Ikner et al., 2007), and the candidate division WS3 has been previously identified from caves in Spain (Schabereiter-Gurtner et al., 2004). The significance of why there were relatively low numbers of clones retrieved from the moonmilk for these phyla is unknown, particularly for the Actinobacteria that have been shown to play a role in the formation of moonmilk by Cañaveras et al. (2006) and organic matter degradation (e.g., Laiz et al., 2000).

Although the Grotta della Foos and Bus della Genziana moonmilk bacterial diversity was statistically similar to each other, the bacteria appear to be distinct taxonomically, especially at the genus level, from previously examined natural and humanimpacted cave-wall habitats (e.g., Groth \& SaizJimenez, 1999; Vlasceanu et al., 2000; Holmes et al., 2001; Northup \& Lavoie, 2001; Northup et al., 2003; Barton \& Northup, 2007; Barton et al., 2007; Ikner et al., 2007) (Fig. 5). Some of the groups retrieved from the moonmilk were more closely related to each other than to environmental clones or strains from other habitats. But, the overlying soil and percolation waters for both caves are considered to be the primary inoculation source(s) for the moonmilk communities. As such, there were also a high number of phylogenetic associations (at $>93 \%$ sequence identity) between moonmilk clones and environmental clones or cultured strains from soil (e.g., permafrost, forest, grassland) or freshwater systems (e.g., ice, lakes, streams, groundwater), at almost equal representation for all sequence similarity levels (Fig. 5). In terms of the relative proportions of major taxonomic divisions, the community composition from the moonmilk more closely resembles the composition reported in several studies of freshwater systems not soils, featuring over 50\% Proteobacteria, mostly from the Betaproteobacteria, followed by Bacteroidetes, and by rare Verrucomicrobia and Actinobacteria (e.g., Zwart et al., 2002; Newton et al., 2006). These associations provide a unique perspective on the microbial diversity of moonmilk because moonmilk is a potentially novel habitat type in karst and the relatively low diversity and dominance among certain bacterial groups could be due to the moonmilk being a specialized habitat that would favor a variety of metabolic specialists (e.g., Smith, 2007).

Although $6 \%$ of the clones had close affinities to sequences previously retrieved from organicrich material, such as manure and sludge (Fig. 5), there is no such organic-rich contribution to the moonmilk from the surface. There is potential that the composition and structure of the moonmilk bacterial communities in both caves may be influenced from fecal material or gut flora from the beetles that graze the moonmilk. However, previous research of arthropod gut flora has indicated that guts contain an abundance of fermentative microbes, and lactogenic and acetogenic groups (Egert et al., 2003) that would likely not be sustained in the moonmilk geochemical system. Moreover, our recent examination of the Cansiliella gut flora (Paoletti et al., 2013) reveals that Firmicutes represented $>58 \%$ of all retrieved 16 S rRNA gene sequences from clone libraries constructed from guts from three individuals, and that Bacteroidetes represented $\sim 16 \%$ of the sequences, Actinobacteria $11.5 \%$, Deltaproteobacteria $8 \%$, and $<5 \%$ each of the alpha- and betaproteobacterial classes. Consequently, there was no similarity or affinity of the gut clones to sequences retrieved from the moonmilk, suggesting that there is little correspondence between the gut flora and the potential food source for the beetles.

\section{Conclusions - implications for a moonmilk-based food web}

Excluding sulfur-based cave ecosystems where chemolithoautotrophic microbes are primary producers (e.g., Sarbu et al., 1996; Porter et al., 2009), most microbes in cave ecosystems are generally considered to be degraders of allochthonous organic material, depending on the hydrologic connectivity of the cave to the surface, and/or food for higher level organisms. It is unlikely that the micro- and meiofaunal 


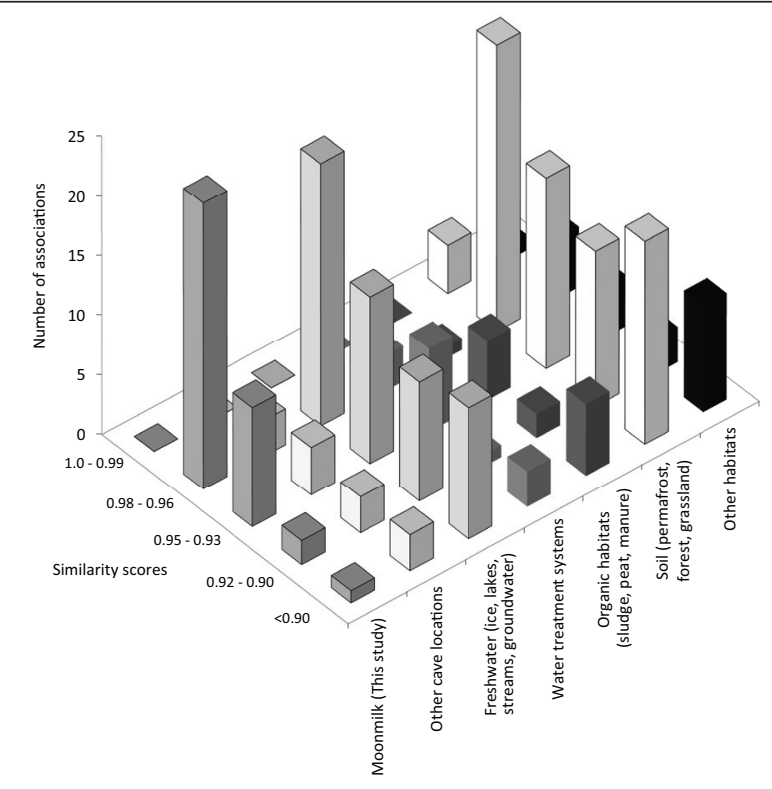

Fig. 5. The number of phylogenetic associations for moonmilk clones to environmental clones and cultured strains from specific habitat types that are described in the literature according to similarity (as $\mathrm{S}$ ab) scores determined by RDP. Scores of 1.0 are for identical sequences. The closer the score to 1.0, the more similar sequences are to each other. Scores $>0.96$ loosely correlate to genus-level associations.

densities are high enough to support higher trophic levels (e.g., Simon et al., 2003; Simon et al., 2007). Based on observations of $C$. servadeii foraging on the moonmilk (Paoletti et al., 2011; Paoletti et al., 2013), we consider that the beetles feed directly on the microbial biofilms incorporated within the moonmilk structure. We suspect that the high microbial biomass within the moonmilk alone could serve as the base of a food web, but future work will need to measure the rates of microbial primary productivity specifically from the moonmilk. Further support for our hypothesis may come from the average organic $\mathrm{C}: \mathrm{N}$ ratio for the moonmilk being $9.4( \pm 1.3)$ (Paoletti et al., 2011). This ratio implies that the nutritional quality of the moonmilk is potentially greater than plant-derived food, which would be $\sim 15$ to $>700$ depending on plant species or soil type (e.g., Snowdon et al., 2005). In general, ratios $>5$ indicate an abundant carbon supply but a potential reduction in nitrogen availability due to storage of microbial biomass and nitrogen remineralization by microbes, which would have a $\mathrm{C}: \mathrm{N}$ ratios for the biomass of $\sim 2-8$, depending on the cell type (Anderson, 1992).

Acknowledging that phylogeny does not yield unequivocal metabolic information (e.g., Achenbach \& Coates, 2000; Rodriguez-Valera, 2002), and the clone libraries were not as exhaustively sampled as possible, there is still some indication from the 16S rRNA gene sequence data that the active metabolism of microbes within the moonmilk influences the geochemistry of the potential moonmilk-based food web. Specifically, the prevalence of microbes associated with the nitrogen cycle, and the detectable concentrations of nitrate, nitrite, and ammonium in the percolating waters, further point to an active nitrogen cycle that would affect how the trophic status is interpreted from stable isotope ratio analyses (Paoletti et al., 2011). Because the C:N ratio is $>5$, this would also force the animals to browse and process moonmilk constantly to achieve sufficient organic N. Browsing behavior by Cansiliella spp. would aerate the top of the moonmilk in contact with the percolating waters, and this could not only affect the precipitation dynamics of carbonate minerals within the moonmilk, but also affect the microbial community structure and system geochemistry associated with carbon and nitrogen cycling. These results provide unique insight into the types of food webs that can develop in cave and karst habitats and offer important implications regarding the evolutionary adaptations of animals such as Cansiliella that exploit a hygropetric habitat.

\section{ACKNOWLEDGEMENTS}

Speleological groups from Pradis, the Gruppo Speleologico Idrologico Friulano, Udine, and the Unione Speleologica Pordenonese are acknowledged for their support on cave trips. Suggestions of fieldwork, figures, and photos were provided by M. Foissner, V. Toniello, G. Concina, R. Mazzaro, M. Simonetti, R. Caicci, and L. Salmaso. We thank O. Coppellotti, S. Rota, and U. Ferrarese for assistance in meiofaunal identification. The research and manuscript benefited from the input by B. Jalzic, L. Latella, O. Moldovan, J. Mulec, M.L. Porter, U. Sauro, B. Sket, and two anonymous reviewers.

\section{REFERENCES}

Achenbach, L.A. \& Coates, J.D., 2000 - Disparity between bacterial phylogeny and physiology. ASM News, 66: 714-715.

Addison, S.L., Foote, S.M., Reid, N.M. \& Lloyd-Jones, G., 2007 - Novosphingobium nitrogenifigens sp. nov., a polyhydroxyalkanoate-accumulating diazotroph isolated from a New Zealand pulp and paperwastewater. International Journal of Systematic and Evolutionary Microbiology, 57: 2467 - 2471.

http://dx.doi.org/10.1099/ijs.0.64627-0

Amend, J.P. \& Teske, A., 2005 - Expanding frontiers in deep subsurface microbiology. Palaeogeography, Palaeoclimatology, Palaeoecology, 219: 131-155.

http://dx.doi.org/10.1016/j.palaeo.2004.10.018

Anderson, T.R., 1992 - Modelling the influence of food C:N ratio, and respiration on growth and nitrogen excretion in marine zooplankton and bacteria. Journal of Plankton Research 14: 1645-1671.

http://dx.doi.org/10.1093/plankt/14.12.1645

Baker, G.C. \& Cowan, D.A., 2004 - 16S rDNA primers and the unbiased assessment of thermophile diversity. Biochemical Society Transactions, 32: 218-221. http://dx.doi.org/10.1042/BST0320218

Barton, H.A. \& Northup, D.E., 2007 - Geomicrobiology in cave environments: past, current and future perspectives. Journal of Cave and Karst Studies, 69: 163-178.

Barton, H.A., Taylor, N.M., Lubbers, B.R. \& Pemberton, A.C., 2006 - DNA extraction from low-biomass carbonate rock: An improved method with reduced contamination and the low-biomass contaminant database. Journal of Microbiological Methods, 66: 21-31.

http://dx.doi.org/10.1016/j.mimet.2005.10.005

Barton, H.A., Taylor, N.M., Kreate, M.P., Springer, A.C., Oehrle, S.A. \& Bertog, J.L., 2007 - The impact of host rock geochemistry on bacterial community structure in oligotrophic cave environments. International Journal of Speleology, 36: 93-104.

http://dx.doi.org/10.5038/1827-806X.36.2.5 
Baskar, S., Baskar, R. \& Routh, J., 2011 - Biogenic evidences of moonmilk deposition in the Mawmluh cave, Meghalaya, India. Geomicrobiology Journal, 28: 252-265.

http://dx.doi.org/10.1080/01490451.2010.494096

Beggio, M., 2007 - Nuova catena alimentare basata su batteri autolitotrofici in ambiente carsico profondo friulano? Ipotesi su Cansiliella., University of Padova, Italy.

Birdwell, J.E. \& Engel, A.S., 2009 - Variability in terrestrial and microbial contributions to dissolved organic matter fluorescence in the Edwards Aquifer, Central Texas. Journal of Cave and Karst Studies, 71: 144-156.

Birdwell, J.E. \& Engel, A.S., 2010 - Characterization of dissolved organic matter in cave and spring waters using UV-Vis absorbance and fluorescence spectroscopies. Organic Geochemistry, 41: 270-280. http://dx.doi.org/10.1016/j.orggeochem.2009.11.002

Blyth, A.J., Baker, A., Collins, M.J., Penkman, K.E.H., Gilmour, M.A., Moss, J.S., Genty, D. \& Drysdale, R.N., 2008 - Molecular organic matter in speleothems and its potential as an environmental proxy. Quaternary Sceince Reviews, 27: 905-921.

http://dx.doi.org/10.1016/j.quascirev.2008.02.002

Borsato, A., Frisia, S., Jones, B. \& van der Borg, K., 2000 - Calcite moonmilk: crystal morphology and environment of formation in caves in the Italian Alps. Journal of Sedimentary Research, 70: 1179-1190.

http://dx.doi.org/10.1306/032300701171

Braissant, O., Bindschedler, S., Daniels, A.U., Verrecchia, E.P. \& Cailleau, G., 2012 - Microbiological activities in moonmilk monitored using isothermal microcalorimetry (Cave of Vers Chez le Brandt, Neuchatel, Switzerland). Journal of Cave and Karst Studies, 74: 116-126. http://dx.doi.org/10.4311/2011JCKS0213

Cacchio, P., Contento, R., Ercole, C., Cappuccio, G., Preite Martinez, M. \& Lepidi, G., 2004 - Involvement of microorganisms in the formation of carbonate speleotherms in the Cervo Cave (L'Aquila-Italy). Geomicrobiology Journal, 21: 497-509. http:/ /dx.doi.org/10.1080/01490450490888109

Cañaveras, J.C., Cuezva, S., Sanchez-Moral, S., Lario, J., Laiz, L., Gonzalez, J.M. \& Saiz-Jimenez, C., 2006 - On the origin of fiber calcite crystals in moonmilk deposits. Naturwissenschaften, 93: 27-32. http:/ /dx.doi.org/10.1007/s00114-005-0052-3

Chelius, M.K. \& Moore, J.C., 2004 - Molecular phylogenetic analysis of Archaea and Bacteria in Wind Cave, South Dakota. Geomicrobiology Journal, 21: 123-134.

http://dx.doi.org/10.1080/01490450490266389

Cole, J.R., Wang, Q., Cardenas, E., Fish, J., Chai, B., Farris, R.J., Kulam-Syed-Mohideen, A.S., McGarrell, D.M., Marsh, T., Garrity, G.M. \& Tiedje, J.M., 2009 The Ribosomal Database Project: improved alignments and new tools for rRNA analysis. Nucleic Acids Research, 37: D141-D145. http://dx.doi.org/10.1093/nar/gkn879

Curry M.D., Boston P.J., Spilde M.N., Baichtal J.F., \& Campbell A.R. 2009 - Cottonballs, a unique subaqeous moonmilk and abundant subaerial moonmilk in Cataract Cave, Tongass National Forest, Alaska. International Journal of Speleology, 38: 111-128.

http://dx.doi.org/10.5038/1827-806X.38.2.3

del Giorgio, P.A. \& Cole, J.J., 1998 - Bacterial growth efficiency in natural aquatic ecosystems. Annual Review of Ecology and Systematics, 29: 503-541. http://dx.doi.org/10.1146/annurev.ecolsys.29.1.503

Egert, M., Wagner, B., Lemke, T., Brune, A. \& Friedrich, M.W., 2003 - Microbial community structure in midgut and hindgut of the humus-feeding larva of Pachnoda ephippiata (Coleoptera: Scarabaeidae). Applied and Environmental Microbiology, 69: 6659-6668. http://dx.doi.org/10.1128/AEM.69.11.6659-6668.2003
Eiler, A., Langenheder, S., Bertilsson, S. \& Tranvik, L.J., 2003 - Heterotrophic bacterial growth efficiency and community structure at different natural organic carbon concentrations. Applied and Environmental Microbiology, 69: 3701-3709. http://dx.doi.org/10.1128/AEM.69.7.3701-3709.2003

Farnleitner, A.H., Wilhartitz, I., Ryzinska, G., Kirschner, A.K.T., Stadler, H., Burtscher, M.M., Hornek, R., Szewzyk, U., Herndl, G. \& Mach, R.L., 2005 - Bacterial dynamics in spring water of alpine karst aquifers indicates the presence of stable autochthonous microbial endokarst communities. Environmental Microbiology, 71: 3003-3015.

Gerič, B., Pipan, T. \& Mulec, J., 2004 - Diversity of culturable bacteria and meiofauna in the epikarst of Škocjanske jame caves (Slovenia). Acta Carsologica 33: 301-309.

Giachino, P.M. \& Vailati, D., 2006 - Kircheria beroni, a new genus and new species of subterranean hygropetricolous Leptodirinae from Albania. Subterranean Biology, 4: 103-116.

Gillis, M. \& De Ley, J., 2006 - The Genera Chromobacterium and Janthinobacterium, in The Prokaryotes: A Handbook on the Biology of Bacteria, 3rd edition. edited by $\mathrm{M}$. Dworkin, S. Falkow, E. Rosenberg, K.-H. Schleifer \& E. Stackebrandt, pp. 737-746, Springer, New York.

Goldscheider, N., Hunkeler, D. \& Rossi, P., 2006 Review: Microbial biocenoses in pristine aquifers and an assessment of investigative methods. Hydrogeology Journal, 14: 926-941. http://dx.doi.org/10.1007/s10040-005-0009-9

Gray, C.J. \& Engel, A.S., 2013 - Microbial diversity and impact on carbonate geochemistry across a changing geocemical gradient in a karst aquifer. The ISME Journal, 7: 325-337.

http://dx.doi.org/10.1038/ismej.2012.105

Grimes, D.J., Woese, C.R., MacDonell, M.T. \& Colwell, R.R., 1997 - Systematic study of the genus Vogesella gen. nov. and its type species, Vogesella indigofera comb. nov. International Journal of Systematic Bacteriology, 47: 19-27.

http://dx.doi.org/10.1099/00207713-47-1-19

Groth, I. \& Saiz-Jimenez, C., 1999 - Actinomycetes in hypogean environments. Geomicrobiology Journal, 16: 1-8. http://dx.doi.org/10.1080/014904599270703

Heylen, K., Lebbe, L. \& De Vos, P., 2008 - Acidovorax caeni sp. nov., a denitrifying species with genetically diverse isolates from activated sludge. International Journal of Systematic and Evolutionary Microbiology, 58: 73-77. http://dx.doi.org/10.1099/ijs.0.65387-0

Hill, C.A. \& Forti, P., 1997 - Cave Minerals of the World. 446 pp., National Speleological Society, Huntsville, Alabama.

Holmes, A.J., Tujula, N.A., Holley, M., Contos, A., James, J.M., Rogers, P. \& Gillings, M. R., 2001 - Phylogenetic structure of unusual aquatic microbial formations in Nullarbor caves, Australia. Environmental Microbiology, 3: $256-264$

http://dx.doi.org/10.1046/j.1462-2920.2001.00187.x

Horner-Devine, M.C., Leibold, M.A., Smith, V.H. \& Bohannan, B.J.M., 2003 - Bacterial diversity patterns along a gradient of primary productivity. Ecology Letters, 6: 613-622.

http://dx.doi.org/10.1046/j.1461-0248.2003.00472.x

Hutchens, E., Radajewski, S., Dumont, M.G., McDonald, I.R., \& Murrell, J.C., 2004 - Analysis of methanotrophic bacteria in Movile Cave by stable isotope probing. Environmental Microbiology, 6: 111-120.

http://dx.doi.org/10.1046/j.1462-2920.2003.00543.x Ikner, L.A., Toomey , R.S., Nolan, G., Neilson, J.W., Pryor, B.M. \& Maier, R.M., 2007 - Culturable microbial diversity and the impact of tourism in Kartchner Caverns, Arizona. Microbial Ecology, 53: 30-42. http://dx.doi.org/10.1007/s00248-00006-09135-00248 
Innamorati, M., Ferrari, I., Marino, D. \& D’Alcala, M.R., 1990 - Metodi nell'ecologia del placton marino. Nova Thalassia, 11: 207-223.

Jeannel, R., 1924 - Monographie des Bathsyciinae. Archives de Zoologie Expérimentale et Générale, 63: 1-436.

Jurkevitch, E. \& Davidov, Y., 2006 - Phylogenetic diversity and evolution of predatory prokaryotes. In Jurkevitch, E., ed. Predatory Prokaryotes. Microbiology Monographs, 4: 11-56.

Kumar, S., Tamura, K. \& Nei, M., 2004 - MEGA3: Integrated software for molecular evolutionary genetics analysis and sequence alignment. Briefings in Bioinformatics, 5: 150-163.

http://dx.doi.org/10.1093/bib/5.2.150

Lacelle, D., Lauriol, B. \& Clark, I.D., 2004 - Seasonal isotopic imprint in moonmilk from Caverne de l'Ours (Quebec, Canada): implications for climatic reconstruction. Canadian Journal of Earth Sciences, 41: 1411-1423. http://dx.doi.org/10.1139/e04-080

Laiz, L., Groth, I., Gonzalez, I. Saiz-Jimenez, C., 1999 Microbiological study of the dripping waters in Altamira Cave (Santillana del Mar, Spain). Journal of Microbiological Methods, 36: 129-138. http://dx.doi.org/10.1016/S0167-7012(99)00018-4

Laiz, L., Groth, I., Schumann, P., Zezza, F., Felske, A., Hermosin, B., \& Saiz-Jimenez, C., 2000 - Microbiology of the stalactites from Grotta dei Cervi, Porto Badisco, Italy. International Microbiology, 3: 25-30

Lane, D.J., 1991 - 16S/23S rRNA sequencing, p. 115175., in Nucleic acid techniques in bacterial systematics. edited by E. Stackebrandt \& M. Goodfellow, John Wiley \& Sons, Chichester, United Kingdom.

Li , W.J., Zhang, Y.Q., Park, D.J., Li, C.T., Xu, L.H., Kim, C.J. \& Jiang, C.L., 2004 - Duganella violaceinigra $s p$. nov., a novel mesophilic bacterium isolated from forest soil. International Journal of Systematic and Evolutionary Microbiology, 54: 1811-1814. http://dx.doi.org/10.1099/ijs.0.63141-0

Macalady, J.L., Dattagupta, S., Schaperdoth, I., Jones, D.S., Druschel, G.K. \& Eastman, D., 2008 - Niche differentiation among sulfur-oxidizing bacterial populations in cave waters. The ISME Journal, 2: 590-601.

http://dx.doi.org/10.1038/ismej.2008.25

Mason-Williams, A., 1959 - The formation and deposition of moonmilk. Cave Research Group G.B., Transactions, 10: 135-138.

Midwood, A.J. \& Boutton, T.W., 1997 - Soil carbonate decomposition by acid has little effect on $d^{13} \mathrm{C}$ of organic matter. Soil Biology and Biochemistry, 30: 1301-1307. http://dx.doi.org/10.1016/S0038-0717(98)00030-3

Moldovan, O.T., Jalzic, B. \& Erichsen, E., 2003 - Adaptation of the mouthparts in some subterranean Cholevinae (Coleoptera, Leiodidae). Natura Croatica, 13: 1-18.

Mulec, J., Zalar, P., Zupan-Hajna, N. \& Rupnik, M., 2002 - Screening for culturable microorganisms from cave environments (Slovenia). Acta Carsologica, 31: 177-187.

Newton, R.J., Kent, A.D., Triplett, E.W. \& McMahon, K.D., 2006 - Microbial community dynamics in a humic lake: bacterial assemblages respond differentially to season biological drivers. Environmental Microbiology, 8: 956-970. http://dx.doi.org/10.1111/j.1462-2920.2005.00979.x

Northup, D.E. \& Lavoie, K., 2001 - Geomicrobiology of caves: a review. Geomicrobiology Journal, 18: 199-222. http://dx.doi.org/10.1080/01490450152467750

Northup, D.E., Dahm, C.N., Melim, L.A., Spilde, M.N., Crossey, L.J., Lavoie, K.H., Mallory, L.M., Boston, P.J., Cunningham, K.I. \& Barns, S.M., 2000 - Evidence for geomicrobiological interactions in Guadalupe caves. Journal of Cave and Karst Studies, 62: 80-90.
Northup, D.E., Barns, S.M., Yu, L.E., Spilde, M.N., Schelble, R.T., Dano, K.E., Crossey, L.J., Connolly, C.A., Boston, P.J., Natvig, D.O. \& Dahm, C.N., 2003 - Diverse microbial communities inhabiting ferromanganese deposits in Lechuguilla and Spider Caves. Environmental Microbiology, 5: 1071-1086. http://dx.doi.org/10.1046/j.1462-2920.2003.00500.x

Opsahl, S.P. \& Chanton, J.P., 2006 - Isotopic evidence for methane-based chemosynthesis in the Upper Floridan aquifer food web. Oecologia, 150: 89-96. http://dx.doi.org/10.1007/s00442-006-0492-2

Paoletti, M.G., 1973 - Notizie sistematiche ed ecologiche su di un nuovo interessante genere del Cansiglio Cansiliella. Supplemento Bollettino del Museo Civico di Storia Naturale di Venezia, 24: 81-88.

Paoletti, M.G., 1980 - Dati aggiuntivi alla conoscenza del genere Cansiliella Paoletti (Col. Bathysciinae). Redia, Firenze, 63: 67- 80.

Paoletti, M.G., Beggio, M., Pamio, A., Gomiero, T., Brilli, M., Dreon, A.L., Toniello, V. \& Engel, A.S., 2009 Comparison of three moonmilk cave habitats associated with troglobitic beetles. paper presented at 15th International Congress of Speleology, Kerrville, Texas.

Paoletti, M.G., Beggio, M., Dreon, A.L., Pamio, A., Gomiero, T., Brilli, M., Dorigo, L., Concheri, G., Squartini, A. \& Engel, A.S., 2011 - A new foodweb based on microbes in calcitic caves: The Cansiliella (beetles) case in Northern Italy. International Journal of Speleology, 40: 45-52.

http://dx.doi.org/10.5038/1827-806X.40.1.6

Paoletti, M.G., Mazzon, L., Sanudo, I.Z., Simonato, M., Beggio, M., Dreon, A.L., Pamio, A., Brilli, M., Dorigo, L., Engel, A.S., Tondello, A., Baldan, B., Concheri, G. \& Squartini, A., 2013 - A unique midgut-associated bacterial community hosted by the cave beetle Cansiliella servadeii (Coleoptera: Leptodirini) reveals parallel phylogenetic divergences from universal gutspecific ancestors. BMC Microbiology. http://dx.doi.org/10.1186/1471-2180-13-129

Parkhurst, D.L. \& Appelo, C.A.J., 1999 - User's guide to PHREEQC (Version2)-A computer program forspeciation, batch-reaction, one-dimensional transport, and inversegeochemical calculations, $310 \mathrm{pp}$.

Podar, M., Abulencia, C.B., Walcher, M., Hutchison, D., Zengler, K., Garcia, J.A., Holland, T., Cotton, D., Hauser, L. \& Keller, M., 2007 - Targeted access to the genomes of low-abundance organisms in complex microbial communities. Appllied and Environmental Microbiology, 73: 3205-3214. http://dx.doi.org/10.1128/AEM.02985-06

Porter, K.G. \& Feig, Y.S., 1980 - The use of DAPI for identifying and counting aquatic microflora. Limnology and Oceanography, 25: 943-948.

http://dx.doi.org/10.4319/10.1980.25.5.0943

Porter, M.L., Engel, A.S., Kane, T.C. \& Kinke, B.K., 2009 - Productivity-diversity relationships from chemolithoautotrophically based sulfidic karst systems. International Journal of Speleology, 38: 27-40. http://dx.doi.org/10.5038/1827-806X.38.1.4

Portillo, M.C. \& Gonzalez, J.M., 2011 - Moonmilk deposits originate from specific bacterial communities in Altamira Cave (Spain). Microbial Ecology, 61: 182-189. http://dx.doi.org/10.1007/s00248-010-9731-5

Remy, P., 1940 - Sur le mode de vie des Hadesia dans la grotte Vjetrenica. Revue Française d'Entomologie, 7: 1-8.

Richter, D.K., Immenhauser, A. \& Neuser, R.D., 2008 - Electron backscatter diffraction documents randomly orientated c-axes in moonmilk calcite fibres: evidence for biologically induced precipitation. Sedimentology, 55: 487-497.

http://dx.doi.org/10.1111/j.1365-3091.2007.00915.x 
Rodríguez-Valera, F., 2002 - Approaches to prokaryotic biodiversity: a population genetics perspective. Environmental Microbiology, 4: 628-633.

http://dx.doi.org/10.1046/j.1462-2920.2002.00354.x

Rooney, D.C., Hutchens, E., Clipson, N., Baldini, J. \& McDermott, F., 2010 - Microbial community diversity of moonmilk deposits at Ballynamintra Cave, Co. Waterford, Ireland. Microbial Ecology, 60: 753-761. http://dx.doi.org/10.1007/s00248-010-9693-7

Rusterholtz, K. \& Mallory, L.M., 1994 - Density, activity and diversity of bacteria indigenous to a karstic aquifer. Microbial Ecology, 28: 79-99. http:/ /dx.doi.org/10.1007/BF00170249

Sanchez-Moral, S., Portillo, M.C., Janices, I., Cuezva, S., Fernández-Cortés, A., Cañaveras, J.C. \& Gonzalez, J.M., 2012 - The role of microorganisms in the formation of calcitic moonmilk deposits and speleothems in Altamira Cave. Geomorphology, 139-140: 285-292. http://dx.doi.org/10.1016/j.geomorph.2011.10.030

Sarbu, S.M., Kane, T.C. \& Kinkle, B., 1996 - A chemoautotrophically based cave ecosystem. Science 272: 1953-1955.

http://dx.doi.org/10.1126/science.272.5270.1953

Schabereiter-Gurtner, C., Saiz-Jimenez, C., Piñar, G., Lubitz, W. \& Rölleke, S., 2002a - Altamira Cave Paleolithic paintings harbour partly unknown bacterial communities. FEMS Microbiology Letters, 211: 7-11. http://dx.doi.org/10.1111/j.1574-6968.2002.tb11195.x

Schabereiter-Gurtner, C., Saiz-Jimenez, C., Pinar, G., Lubitz, W. \& Rolleke, S., 2002b - Phylogenetic 16S rRNA analysis reveals the presence of complex and partly unknown bacterial communities in Tito Bustillo Cave, Spain, and on its Palaeolithic paintings. Environmental Microbiology, 4: 392-400.

http://dx.doi.org/10.1046/j.1462-2920.2002.00303.x

Schabereiter-Gurtner, C., Saiz-Jimenez, C., Piñar, G., Lubitz, W. \& Rölleke, S., 2004 - Phylogenetic diversity of bacteria associated with Paleolithic paintings and surrounding rock walls in two Spanish caves (Llonin and La Garma). FEMS Microbiology Ecology, 47: 235-247. http://dx.doi.org/10.1016/S0168-6496(03)00280-0

Schloss, P.D. \& Handelsman, J., 2005 - Introducing DOTUR, a computer program for defining operational taxonomic units and estimating species richness. Applied and Environmental Microbiology, 71: 1501-1506. http://dx.doi.org/10.1128/AEM.71.3.1501-1506.2005

Simon, K., Benfield, E.F. \& Macko, S.A., 2003 - Food web stucture and the role of epilithic biofilms in cave streams. Ecology, 84: 2395-2406.

http://dx.doi.org/10.1890/02-334

Simon, K.S., Pipan, T. \& Culver, D.C., 2007 - A conceptual model of the flow and distribution of organic carbon in caves. Journal of Cave and Karst Studies, 69: 279-284.
Sket, B., 2004 - The cave hygropetric - a little known habitat and its inhabitants. Archiv für Hydrobiologie, 160: 413-425. http://dx.doi.org/10.1127/0003-9136/2004/0160-0413

Smith, V.H., 2007 - Microbial diversity-productivity relationships in aquatic ecosystems. FEMS Microbiology Ecology, 62: 181-186.

http://dx.doi.org/10.1111/j.1574-6941.2007.00381.x

Snowdon, P., Ryan, P. \& Raison, J., 2005 - Review of C:N Ratios in Vegetation, Litter and Soil under Australian Native Forests and Plantations, National Carbon Accounting System - Technical Report No. 45. Australia for the Australian Greenhouse Office in the Department of the Environment and Heritage, 72 pp.

Stackebrandt, E. \& Goebel, B.M., 1994 - A place for DNA-DNA reassociation and 16 S ribosomal-RNA sequence-analysis in the present species definition in bacteriology. International. Journal of Systematic Bacteriology, 44: 846-849. http://dx.doi.org/10.1099/00207713-44-4-846

Strous, M., Heijnen, J.J., Kuenen, J.G. \& Jetten, M.S.M., 1998 - The sequencing batch reactor as a powerful tool for the study of slowly growing anaerobic ammoniumoxidizing microorganisms. Applied Microbiology and Biotechnology, 50: 589-596. http://dx.doi.org/10.1007/s002530051340

Tamura , K., Nei, M. \& Kumar, S., 2004 - Prospects for inferring very large phylogenies by using the neighborjoining method. PNAS, 101: 11030-11035. http://dx.doi.org/10.1073/pnas.0404206101

Van de Kamp, J.L., 2004 - Microbial diversity in Tasmanian caves [Unpublished PhD dissertation], 174 pp, The University of Tasmania.

Vlasceanu, L., Sarbu, S.M., Engel, A.S. \& Kinke, B.K., 2000 - Acidic cave-wall biofilms located in the Frasassi Gorge, Italy. Geomicrobiology Journal, 17: 125-139. http://dx.doi.org/10.1080/01490450050023809

Wang, Q., Garrity, G.M., Tiedje, J.M. \& Cole, J.R., 2007 Naïve Bayesian classifier for rapid assignment of rRNA sequences into the new bacterial taxonomy. Applied and Environmental Microbiology, 73: 5261-5267. http://dx.doi.org/10.1128/AEM.00062-07

Wright, E.S., Yilmaz, L.S. \& Noguera, D.R., 2011 DECIPHER: A search-based approach to chimera identification for 16S rRNA sequences. Applied and Environmental Microbiology, 78: 717-725. http://dx.doi.org/10.1128/AEM.06516-11

Zwart, G., Crump, B.C., Agterveld, M., Hagen, F. \& Han, S.K., 2002 - Typical freshwater bacteria: an analysis of available 16S rRNA gene sequences from plankton of lakes and rivers. Aquatic Microbial Ecology, 28: 141-155. http://dx.doi.org/10.3354/ame028141 